Marinita Stiglitz* and Julia Bearman

\title{
Of Earth and Sky: A Pair of Ming Hanging Scrolls, from Past Repairs to Present Conservation
}

DOI 10.1515/res-2016-0011

Received July 11, 2016; revised September 15, 2016; accepted October 3, 2016

Abstract: A pair of Chinese scrolls representing the earth and sky were donated to the Bodleian Library in 1684. They are thought to be ephemeral items printed during the late Ming dynasty. Records indicate that in 1883 the scrolls were trimmed, patched with transparent paper, backed with cloth and mounted in an unsympathetic manner. In this paper, we consider the conservation and preservation measures adopted by the then Bodleian Librarian and reflect on his participation at the St. Gall Conference in 1898. The conservation treatment of the scrolls completed in 2015 was guided by their past repairs, current ethical considerations and scientific analysis. Breaking the strong bond between the transparent paper and the fragile surface of the scrolls required experimentation with the Albertina Compress and Gellan gum. The recreation of functional hanging scrolls involved the use of traditional scroll-mounting techniques and the reinterpretation of the Chinese mounting style from a western conservation perspective. We also discuss the experience gained in treating two artefacts with almost identical problems.

Keywords: Chinese scrolls, historical repairs, Albertina Compress, lining, Gellan gum

\section{Historical context}

On 30th September and 1st October 1898 an international conference took place in St. Gall Switzerland to discuss the preservation of manuscripts. The conference, organised by Father Franz Ehrle, Prefect of the Vatican Apostolic Library, was attended by librarians from institutions across Europe, now referred to as - Universität Heidelberg, Bayerische Staatsbibliothek Munich, Bibliothèque

\footnotetext{
*Corresponding author: Marinita Stiglitz, Conservation and Collection Care, Bodleian Libraries, University of Oxford, Broad Street, Oxford OX1 3BG, UK, E-mail: marinita.stiglitz@bodleian.ox.ac.uk Julia Bearman, Conservation and Collection Care, Bodleian Libraries, University of Oxford, Broad Street, Oxford OX1 3BG, UK, E-mail: julia.bearman@bodleian.ox.ac.uk
} 
royale de Belgique Brussels, Bibliothèque nationale de France Paris, Bibliothèque de la Sorbonne Paris, Magyar Nemzeti Múzeum Budapest, Universiteit Leiden, Staatsbibliothek zu Berlin, Kupferstichkabinett Berlin, Hauptstaatsarchiv Dresden, Stiftsbibliothek St. Gallen, Universität Basel, Schweizerische Nationalbibliothek Bern, Zentralbibliothek Zürich and Württembergische Landesbibliothek Stuttgart. The Bodleian Librarian, Edward Williams Byron Nicholson, also attended as the only representative from Britain (Figure 1).

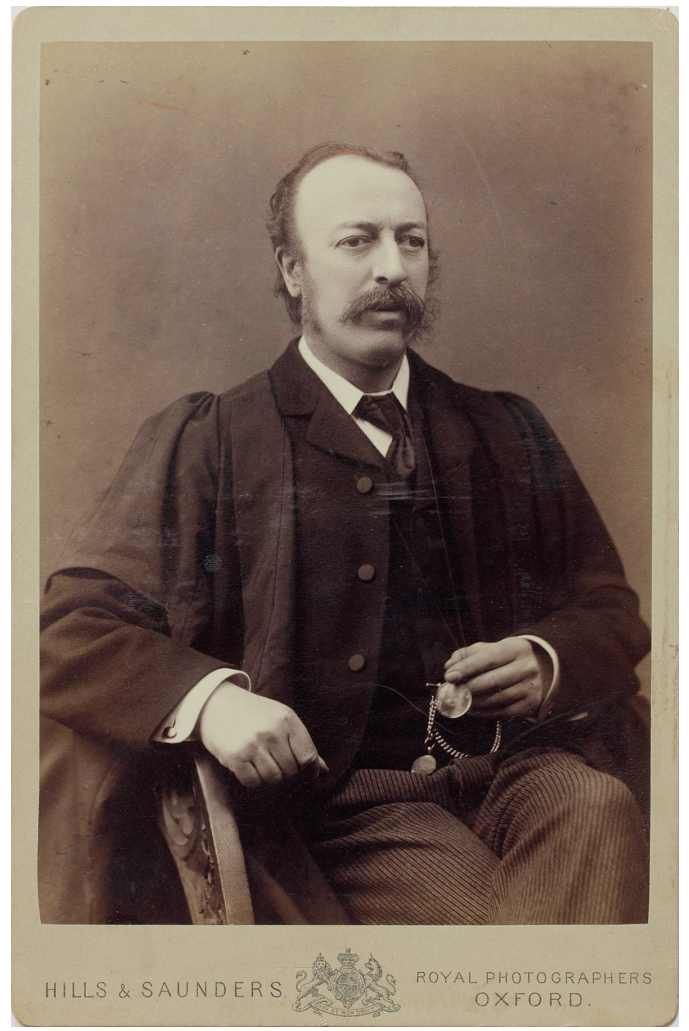

Figure 1: E.W.B. Nicholson, Bodley's Librarian 1882-1912 (The Bodleian Libraries, University of Oxford, Library Records d. 137, fol. 18v).

In his correspondence inviting Nicholson, Ehrle stressed the aim of the conference, which was to address issues of manuscript preservation, examining the oldest and most important manuscripts and the systems to mend and preserve them. With his invitation, Ehrle included a paper he had written stressing the damage caused by the practice of repairing fragile manuscripts with overlays of transparent paper, citing as an example what he saw as the deterioration caused by this method to some fragments of a tenth-century codex at the Bodleian - the Hebrew Ecclesiasticus, MS. Heb. e. 62 (Ehrle 1898). Nicholson, a supporter of repairing damaged collections with 
transparent paper from the time of his arrival at the Bodleian in 1883, was alerted by Ehrle's comment and prepared accordingly for the debate to come.

Looking at Nicholson's papers and correspondence, it is clear that beyond the many pressures of running the Bodleian, he was engaged in, and entirely responsible for, the preservation and repair of manuscripts. A guard-book of great interest containing most of his records relating to the conference (The St. Gallen Conference 1898) includes an experiment through which he compares the methods commonly used by the delegate librarians to repair manuscripts. For this experiment he stuck actual samples of transparent paper, goldbeater's skin, silk crepeline and Japanese paper onto a page of newspaper either with paste or gum (Figure 2). In so doing he could compare them and be guided by his own

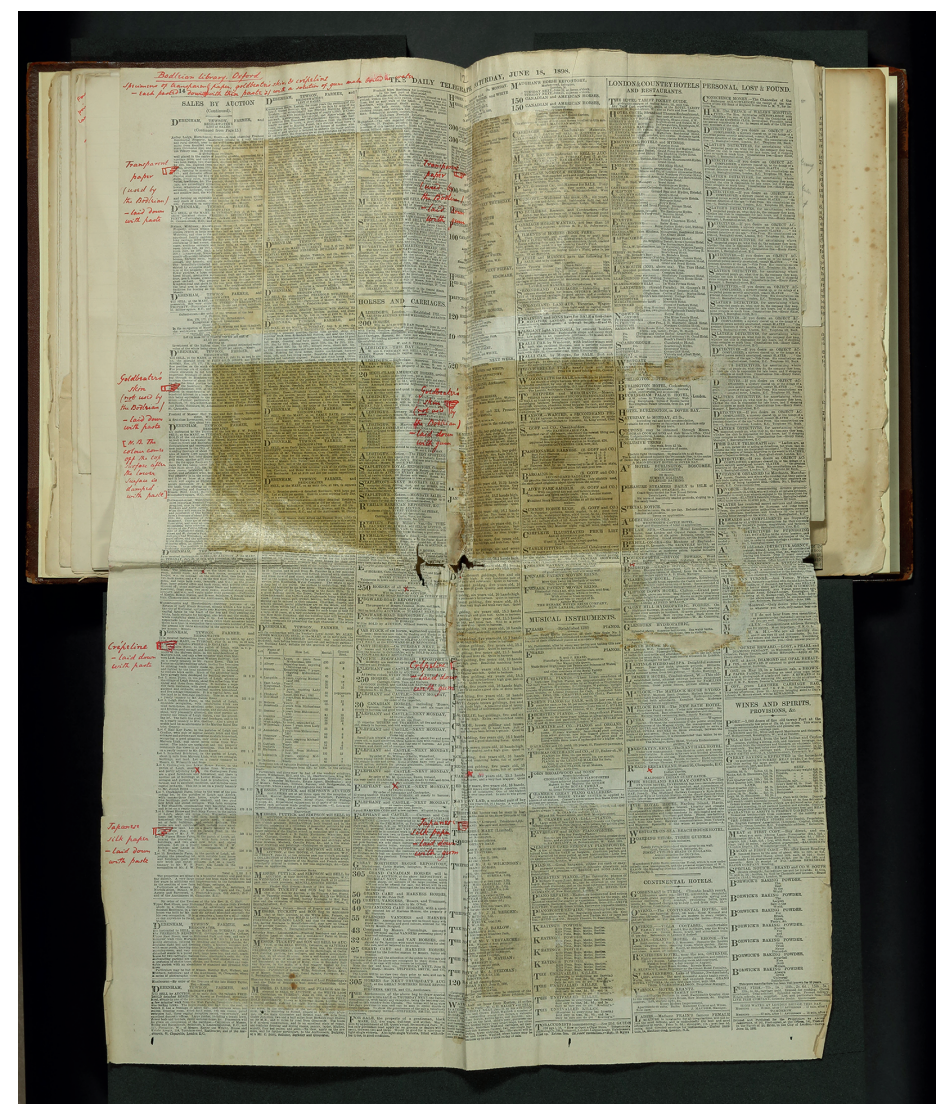

Figure 2: E.W.B. Nicholson's samples of repair material. From the top: transparent paper, goldbeater's skin, silk crepeline, Japanese paper (The Bodleian Libraries, University of Oxford, Library Records c. 1429). 
observations. The sample of transparent paper was a French product used at the Bodleian from 1891 and supplied by George Rowney \& Co. London (Figure 3). The sample of silk crepeline was obtained by Nicholson from Ehrle; the latter had just begun advocating its use at the Vatican Library as a superior type of material for paper repair and of which he sourced nothing less than sixty metres of a suitable thickness and neutral colour from the silk manufacturer Maison Brunet Lacombe in Lyon (Figure 4). Accepting that the crepeline was the most transparent, Nicholson did however comment that it gave the text a hazy appearance, it was much more expensive than transparent paper, it would take longer to lay down and could present unknown drawbacks such as darkening in the years ahead (Nicholson 1898). He remarked that the difference between the Japanese paper and the transparent paper was negligible, while Ehrle, in the paper sent to Nicholson prior to the conference, distinguishes between the two and recognises the stability of the Japanese paper even though his preference was for crepeline (Ehrle 1898). Nicholson had no doubt that the goldbeater's skin was unsuitable. Not only was it too dark but it also left a

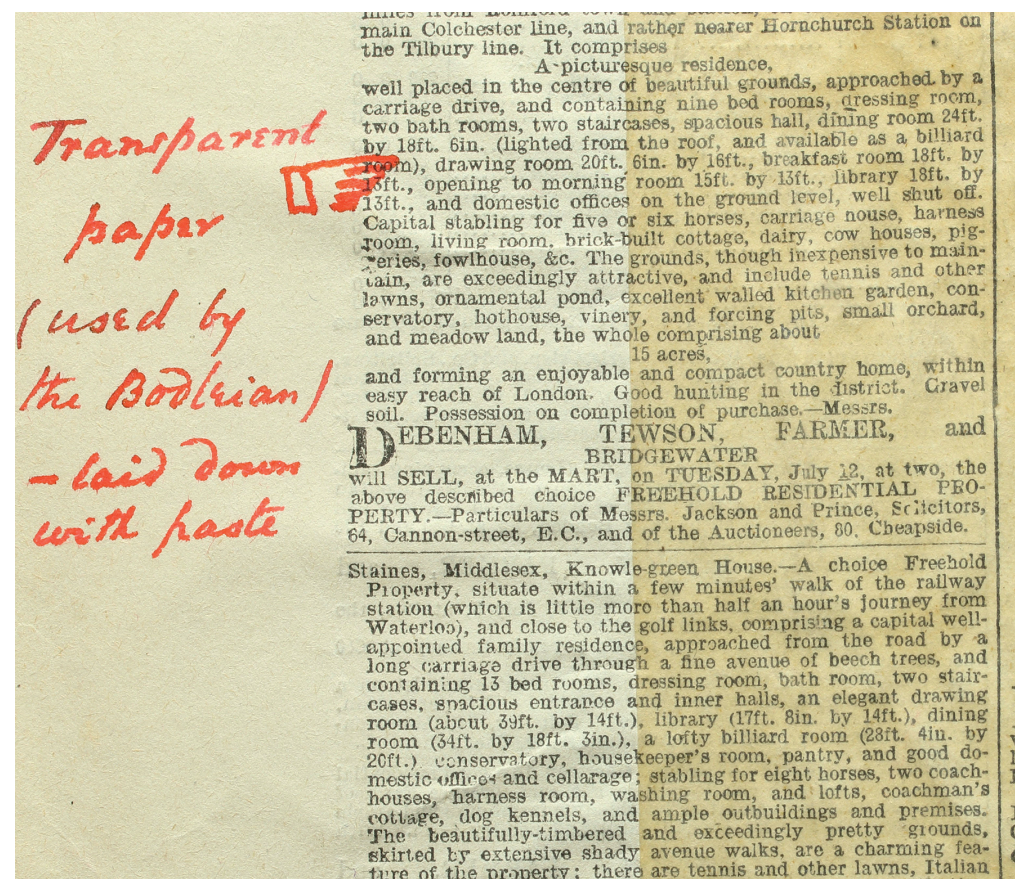

Figure 3: Detail of transparent paper (The Bodleian Libraries, University of Oxford, Library Records C. 1429). 


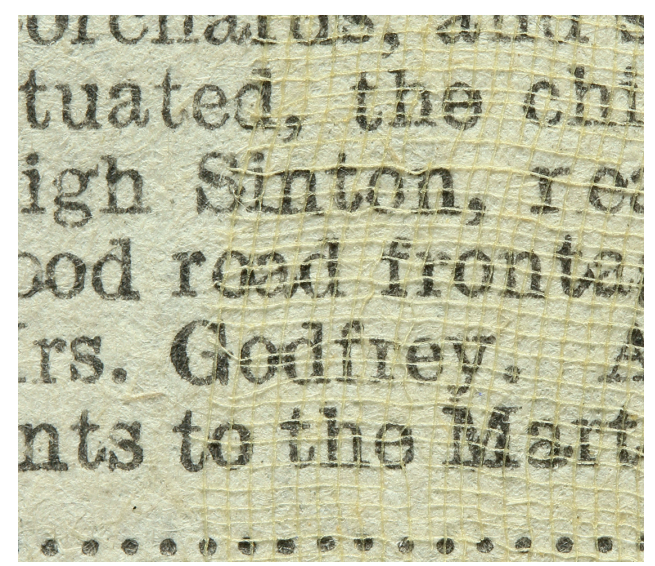

Figure 4: Detail of silk crepeline (The Bodleian Libraries, University of Oxford, Library Records c. 1429).

yellow stain on a piece of paper that he had pressed against its surface. Over a century later the samples still produce much the same reaction, even if today they would not appeal to the conservator.

In preparation for the conference, Nicholson looked at a number of manuscripts overlaid with transparent paper over the past fifteen years at the Bodleian, commenting on the appearance of the transparent paper and whether it had discoloured or remained clear (The St. Gallen Conference 1898). Following this survey, Nicholson continued to uphold his method, especially because he thought it had passed the test of time compared to other materials, and despite an unsuccessful attempt to remove transparent paper from a valuable manuscript at the Bodleian in 1891 (Bodleian Library Papers 1888 - 1892). In response to Ehrle's earlier criticism, he brought to the conference some photographs of the Hebrew Ecclesiasticus before treatment (MS. Heb. e. 67). He wanted to show that the leaves were in the same condition after overlaying as they were before. Using photography to report the condition was innovative but the elusiveness of these particular images is immediately apparent when looking at the manuscript today; the images appear faint and do not reveal the topography of the manuscript's surface. On the other hand, the developing role that photographic reproductions could play in preserving the images of rare and degraded manuscripts was recognized by the St. Gall delegates and suggested as a focus for further collaboration.

\section{Maps of the earth and the sky}

Among the many items repaired in 1883, there were "two Chinese rolls". Described as such in the Binder's book for that year, they are listed without 
shelfmarks unlike most of the other items, indicating that this short description was enough to identify what must have been an uncommon type of material to reach the workroom (Binders Book January 1883 - May 27 1885). Their repair style and the fact that no other Chinese rolls appear in the lists suggests that these are most likely the pair of Ming scrolls discussed in this paper. They were overlaid with transparent paper and backed with cloth and treated as any other rolled item in the collection at the time - a protective parchment flap attached at one end and a roller at the other - losing in this way their original hanging scroll format. In 2011, David Helliwell, the Curator of Chinese Collections, came to discuss their unstable condition and, wishing to display them, he was especially concerned about their appearance because of the disfiguring transparent paper and additions. Furthermore, they could not be hung (Figures 5 and 6).

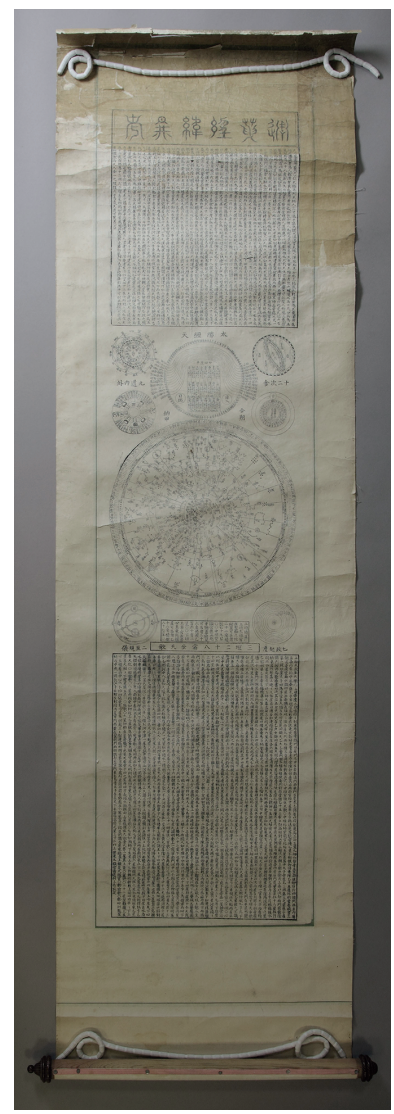

Figure 5: Celestial map before conservation (The Bodleian Libraries, University of Oxford, Sinica 123/1). 


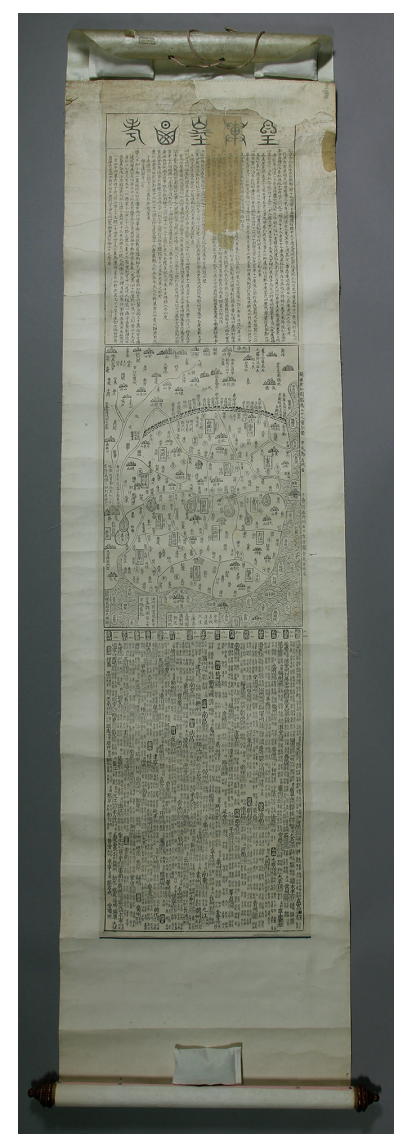

Figure 6: Terrestrial map before conservation (The Bodleian Libraries, University of Oxford, Sinica 123/2).

The Bodleian Library started forming its Chinese collection soon after opening in 1602 at a time when Chinese books could not be read and were considered curious objects. In 1684, these scrolls were given to the Bodleian by George White, an East India Company merchant, and recorded in the Benefactors' Register as two Chinese maps depicting the earth and the sky (Benefactors' Register). The celestial map, with a star map at its centre, and the terrestrial map, depicting the Chinese empire at its centre, are thought to be a rare survival dating back to the late Ming or early Qing Dynasty (mid-seventeenth century). They were perhaps used for teaching purposes in local schools or academies.

Each map was printed in black ink on one sheet of Chinese paper using three finely detailed woodblocks. Each still retained part of the original hanging scroll mounting consisting of what looked to be the original Chinese paper lining as well as a simple paper border attached with strips of dyed paper (the dye was 
identified as indigo through Raman analysis). The celestial map's overall dimensions including the remains of the paper borders were $1,538 \times 411 \mathrm{~mm}$ (length by width) while the terrestrial map measured $1,512 \times 397 \mathrm{~mm}$. It was immediately noticeable that the scrolls had lost the original proportions of a Chinese mounting style, having been trimmed particularly at the top and bottom. This was most likely done to remove heavily damaged areas. In order to decide how to present the maps, their possible original appearance and use were discussed at length with the curator. The remounting posed aesthetic questions together with technical challenges, associated with the removal of the old repairs and the damage they had caused. The flexibility of the thin Chinese paper on which the maps were printed was critically compromised by the robust cloth lining over the old Chinese paper lining on the verso and the now discoloured and brittle transparent overlays bonded to the fragile printed surfaces (Figure 7).

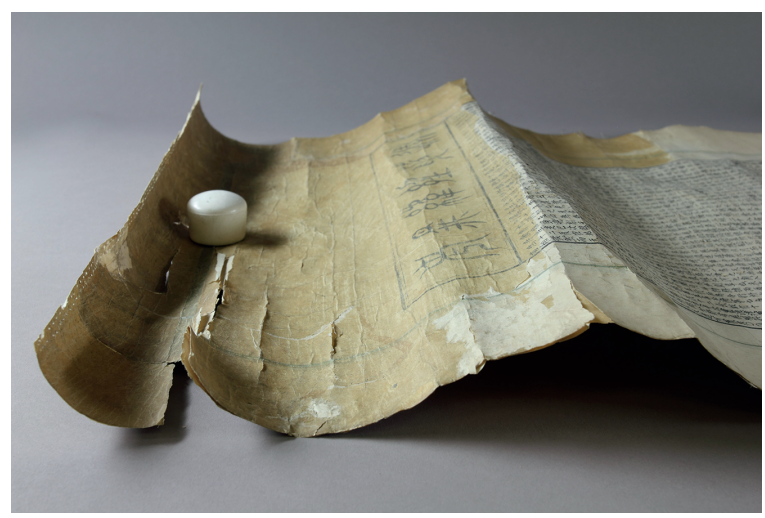

Figure 7: Detail of the celestial map before conservation, showing damage caused by the cloth lining and the overlay of transparent paper (The Bodleian Libraries, University of Oxford, Sinica 123/1).

\section{Conservation treatment}

The celestial map was the first to be treated. The initial technical challenge was how to humidify and flatten this long fragile item so that the cloth lining could be peeled away followed by the outer layer of the Chinese paper lining. By only removing the outer layer, the indigo strips of paper remained undisturbed and at the same time the thickness of the scrolls was reduced enough so the scrolls could regain flexibility with the addition of new linings. The media were found to be stable to water during pre-treatment testing, therefore a gradual humidification 
was introduced by misting with dahlia sprays and brushing down several layers of rayon paper on both recto and verso with water and a misubake (a Japanese brush used to apply water). Rayon paper is a semi-synthetic material made from purified cellulose, with qualities of smoothness and flexibility combined with an ability to stretch when wet. This made it a very useful material for this instance; the first layer was always a sheet of rayon $12 \mathrm{~g} / \mathrm{m}^{2}$, which, being quite thin, moulded itself to the contours of the surface and stayed firmly in contact. This was followed by further layers of rayon $12 \mathrm{~g} / \mathrm{m}^{2}$ and $18 \mathrm{~g} / \mathrm{m}^{2}$ (Figure 8 ). The repeated application of rayon meant that the humidified map could be lifted, smoothed and turned. At the same time it also supported and protected its fragmentary surface, washed some dirt out and softened the adhesive. The map was rested on a layer of blackless (rayon paper $65 \mathrm{~g} / \mathrm{m}^{2}$ ) which absorbed additional discoloration, and was kept damp for a couple of hours under polythene sheeting. This allowed the cloth lining to be peeled away, and soon after, the top layer of the Chinese paper lining was also removed; this was done by working over transmitted light to guide the process.

After this, a temporary lining was adhered with $2 \%$ high viscosity Methocel $^{\circledR}$ $A 4 M$. This consisted of three layers of rayon $12 \mathrm{~g} / \mathrm{m}^{2}$, each layer with the grain direction running counter to the previous. The first layer of rayon was made up

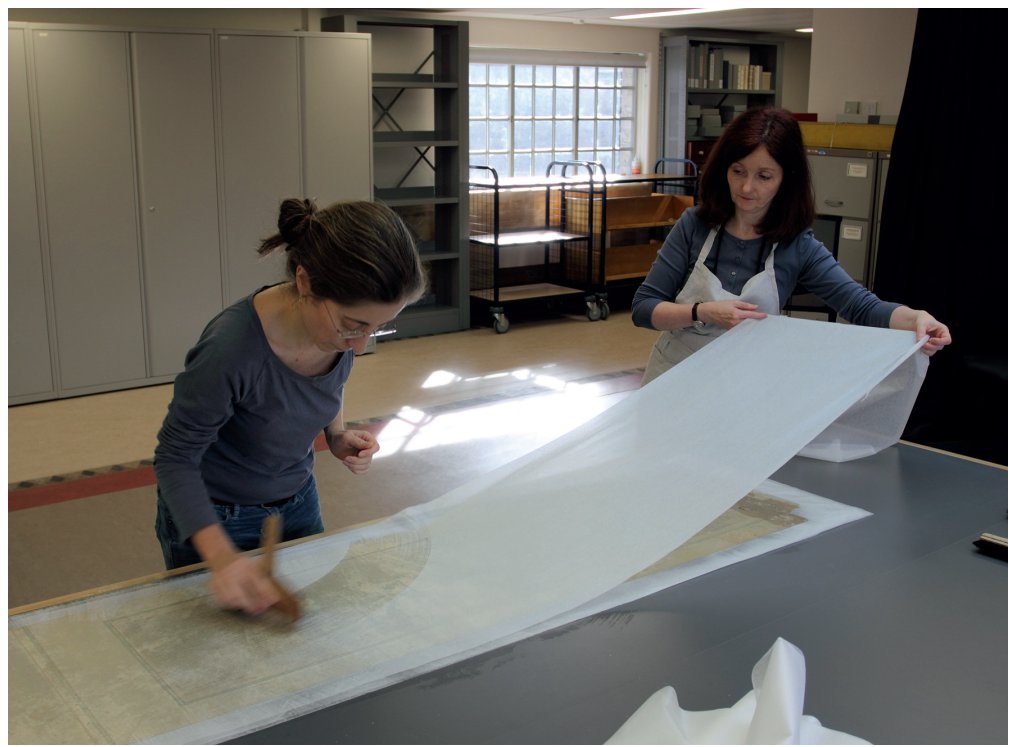

Figure 8: Humidification - brushing down sheets of rayon with water and a misubake (The Bodleian Libraries, University of Oxford). 
of eight pieces so that the application and eventual removal could be safely undertaken. A last layer of sanmoa was then applied - sanmoa made of wood pulp, polyethylene and polypropylene was used in combination with rayon as a support material because it does not stretch as much as rayon and retains its shape. With the temporary lining offering the necessary support, the map could then be dried on the karibari (a Japanese drying board). Later, the map was removed from the karibari and restrained with false margins on a sheet of Plexiglas $^{\circledR}$. The Plexiglas ${ }^{\circledR}$, larger than the map, was previously prepared with strips of Japanese sekishu paper adhered with wheat starch paste along its perimeter so that the false margins could be adhered securely to it with $2.5 \%$ methylcellulose. Controlling the map by temporarily mounting it like this allowed for localised and prolonged humidification; this was necessary for the removal of the transparent paper, whilst maintaining stability and avoiding distortions. Small temporary strips of rayon were applied to fragile areas on the recto of the map in order to hold down any peaking cracks.

The second challenge was the removal of the transparent paper. In preparation for this phase, it was helpful to look at the only other attempt undertaken at the Bodleian. This was carried out in the 1970s when the paper conservator Judy Segal, after considering the damage caused by transparent paper, started experimenting with enzymes, immersing collection material in baths of $\alpha$-amylase followed by protease. This was greeted with optimism at the Bodleian (Vaisey 1974) and she published her methodology and results in the Paper Conservator (Segal and Cooper 1977).

In the case of the maps of the earth and the sky, the aim was to apply a more localised treatment to remove the transparent paper. To help determine a method, the adhesive and tracing paper were analysed; the adhesive was identified with Fourier transform infrared spectroscopy as wheat starch and the transparent paper analysed with an acetone extraction test. The latter showed the presence of a resin. Having established that even after a prolonged humidification process the transparent paper remained firmly adhered to the scrolls, it was decided to apply the commercially available enzymatic poultice, the Albertina Compress (Schwarz 2000), in combination with the rigid gel, Gellan gum (Iannuccelli and Sotgiu 2012). The gel was used as a controlled means of humidification prior to the application of the compress and, after many trials, Gellan gum percentages and exposure times to both gel and compress were established.

The transparent paper was removed as follows. Firstly, three hours humidification with $3 \%$ Gellan gum was necessary to introduce moisture through the transparent paper into the adhesive layer. To maintain contact between the rigid gel and the scroll, a small glass weight was placed on top. Secondly, the gel was removed and the Albertina Compress was applied for two and a half hours whilst keeping the 
area warm with the aid of a rechargeable hand warmer at $35^{\circ} \mathrm{C}$ laid on top of the weight; only then did the adhesive decompose enough so that the transparent paper could be peeled away in small pieces with tweezers and scalpels; some of the adhesive residue was also swabbed from the surface. Finally, the delicate surface of thin Chinese paper was re-humidified and rinsed for half an hour with $2 \%$ Gellan gum. At this stage the gel was laid on rayon to protect the fragile surface of the Chinese paper from its pulling action, otherwise damage and delamination may have occurred. The area was then left to dry. This process could be applied only to a small area at a time, in view of the accuracy required to peel off the transparent paper while the area retained an adequate level of moisture. After the transparent paper was removed, the appearance of the area was discussed and it was decided that it could be improved further. More of the residues were swabbed away after the surface was re-humidified for an hour with $4 \%$ Gellan gum laid on rayon, and by applying the Albertina Compress for an hour. The area was then rinsed again with $2 \%$ Gellan gum.

This method worked well on the celestial map but the approach was modified for the treatment of the terrestrial map not only because of its specific needs - the transparent paper covered a smaller area - but also because of a growing familiarity with the procedure and the materials. As a result, the transparent paper stuck on the surface of the second map was removed using the Gellan gum and Albertina Compress before removing the cloth lining and outer layer of Chinese paper lining. In this case, it was unnecessary to restrain the map on Plexiglas ${ }^{\circledR}$ with a temporary lining. This was beneficial in that it reduced the amount of manipulation undergone by the scroll. Of course, our main concern was that tidelines might appear during the application of gel and compress but we knew that the long humidification period following the removal of the cloth lining would wash out any discolouration and tidelines. The overall treatment was also less time consuming because the removal of the old linings was combined with the application of the first layer of new lining in one single session.

Creating a mounting style for both scrolls presented challenges of a technical and aesthetic nature - on the one hand what was left of the maps' original Chinese hanging scroll format had to be considered and interpreted, whilst on the other hand their long term preservation had to be ensured by providing a flexible support. The maps are deemed a pair but are slightly different in style and dimensions; to emphasize their unity when they are hung together, it was agreed with the curator that the overall lengths of the scrolls should be the same and the titles should be in line. Bearing this in mind the remains of the original borders at the top and bottom were extended to recreate proportions more appropriate to Chinese hanging scrolls. With a final overall length of 2,070 mm the scrolls had a pleasing aesthetic appearance. 
To make the extensions and to infill the losses, thin Xuan paper from Anhui China was selected, as its appearance is very similar to the paper of the maps. This was toned with a solution of watercolour and gelatine and then lined with two layers of Japanese usumino paper adhered with diluted wheat starch paste to echo the thickness of the maps. Before proceeding with the overall lining, the celestial map had to be first released from the Plexiglas ${ }^{\circledR}$. The temporary lining was removed through a supported humidification process using rayon with brush and water, and the surface was blotted with lint free task wipes to remove residues of methylcellulose.

Having considered different combinations of papers, three layers of usumino were selected for the overall lining of the maps. The grain direction of the first and third layer ran with the length of the scrolls and the second counter to the length. Each layer was composed of four pieces of usumino with feathered edges to minimise the overlaps at the joins. The usumino with its long fibres was selected because it offered adequate support not only to each map and its remaining Chinese paper linings but also to its distortions and cracks. It also provided the flexibility and strength necessary for rolling and unrolling as well as preventing the possible reoccurrence of distortions. After the application of each layer of lining, the resulting thickness and flexibility of the scrolls were considered and this informed our choice for the next layer, as did our prior experiments with mock ups.

Each map was flattened and humidified with sheets of rayon then placed face down to receive lightly humidified extensions and infills. Immediately afterwards the first lining was applied. The usumino was pasted with a noribake (a Japanese pasting brush) on a Japanese cypress board using wheat starch adhesive, which had been diluted to a thin consistency. It was then lifted on a wooden stick and brushed down on the verso of the map with a nadebake, (a Japanese smoothing brush). The maps, having been kept evenly damp throughout the procedure, were left to dry between felts and then lightly humidified solely with a misubake and dahlia sprays and attached to a karibari.

They were later released from the karibari and squared. In the past, the original borders had been trimmed imprecisely and to complicate matters further, the printed images were askew. In order to reach a harmonious result, it was necessary to look at all the parts of the scrolls and see how they related to one another. With set squares and long rulers, the positions of the top, bottom, left and right side edges were measured and marked making sure that the latter were parallel to each other and perpendicular to the former. Then, the scrolls were folded bringing the top edge to meet the bottom edge in order to verify the shape before proceeding to cut the sides of the scrolls a few millimetres beyond the original borders. The positions of the envelopes for the stave and rod were 
determined and indicated with a pencil line on the verso. Considerable effort and precision was required at this stage as this procedure would determine whether the finished scrolls would hang well.

The scrolls were humidified, and the second lining applied and then left to dry between felts. False margins of sekishu were attached at this stage to provide the necessary strength to hold the scrolls firmly to the karibari during the final stretching after the third lining. The scrolls were re-humidified in preparation for the third and last lining. They were laid over a light-box and narrow reinforcement strips were applied on the original cracks and peaks. The strips were pasted down by unwinding them from a bamboo spatula. The envelope, which would eventually hold the stave, was lightly humidified and positioned and a line of paste was brushed along its fold and onto the back of the scroll to create a strong bond. This was followed by the application of a third lining, proceeding from the top. Before the last piece of lining was adhered, the envelope for the rod was positioned at the bottom. After the last piece of lining was applied, the corners of the envelopes were strengthened. The reinforcement strips, the envelopes for the stave and rod, and the corners' supports were prepared from usumino with the grain direction conforming to the rolling axis of the scrolls.

For the final time the maps were left to dry overnight between felts. The following day, they were lightly humidified and attached to the karibari with false margins. A gentle puff was directed under the scroll while sticking the borders down; this method helped the surface to dry evenly. The edges of the scrolls were checked further with a straight edge and a stretched cotton thread. Any potential distortions were rectified with gentle manipulation, either by pushing or pulling the scrolls through the false margins.

After a few months, the maps were removed from the karibari and the excess was trimmed. To increase suppleness, the verso of each scroll was smoothed by moving a loop of glass Buddhist prayer beads back and forth across the width of each scroll. Rods, with bone terminals neutral in colour and unadorned, together with wooden staves were prepared and inserted into the respective envelopes at the top and at the bottom of the scrolls; the staves were finished with hanging and wrapping braids (Figures 9 and 10). Finally, hoping to reduce the possible risk of future distortions, the circumferences of the rolled scrolls were increased by preparing roller clamps from archival tubes. Each tube was halved lengthways and hinged on one side with archival linen tape; it was then united on the other side with slings of Japanese paper. In this way the roller could be held in the sling and the scroll rolled around the outside of the tube (Suzuki and Kamba 2009). Once the conservation treatment was completed, the scrolls were ready to be displayed in the Blackwell Hall of the Weston Library, Bodleian Libraries, in the summer of 2015. 


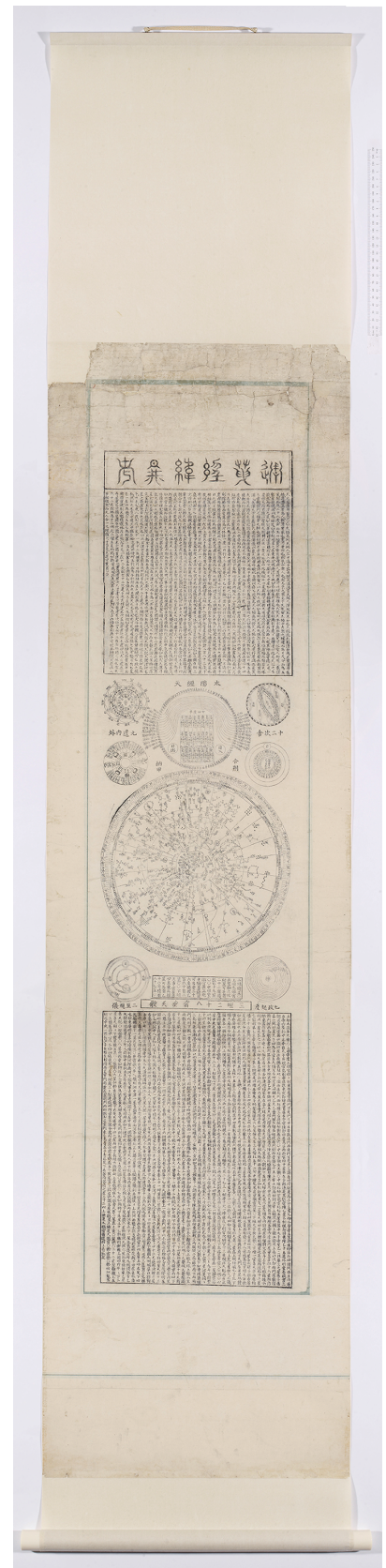

Figure 9: Celestial map after conservation (The Bodleian Libraries, University of Oxford, Sinica 123/1). 


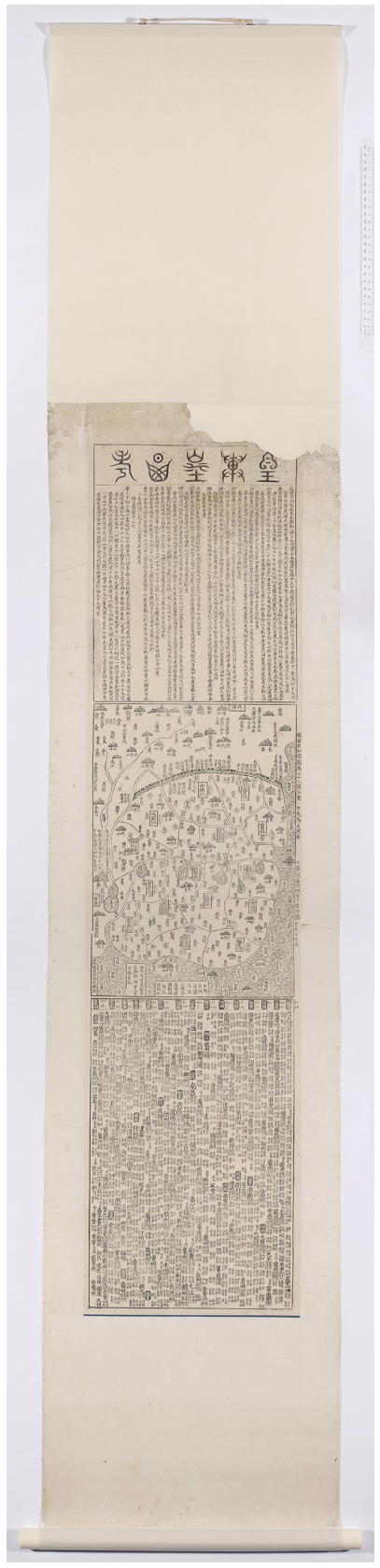

Figure 10: Terrestrial map after conservation (The Bodleian Libraries, University of Oxford, Sinica 123/2). 


\section{Conclusion}

The intention of this paper was to consider the historical context behind the late nineteenth century repairs disfiguring two Ming scrolls, to understand the role played by Nicholson in discussions concerning the preservation of manuscripts, to provide an account of our conservation treatment and to share solutions.

We followed Nicholson's efforts to preserve the Bodleian collections. We looked at the lists, receipts and correspondence pertaining to his dealings with external bindery workshops, his discussions concerning the repair and preservation of manuscripts and the justification of this practice to the University advisory body. Then we looked at manuscripts collections which still retained transparent paper repairs and, from there, at the items treated in the 1970 s by a conservator experimenting with enzymes to remove transparent paper. At that time the repair of the scrolls was also considered but not undertaken because the skills to mount Chinese hanging scrolls were not available at the Bodleian (Helliwell 1977).

Acknowledging the scrolls past history, understanding their condition and valuing their original format prepared the ground for ideas and requirements according to which they were conserved. Critical questions had to be answered - how could the old repairs be safely detached, how much of the old Chinese lining was appropriate to remove and how were losses and damages to be dealt with? Our project linked conservation aspirations and challenges of the past with those of the present and it emphasised the significant role that past treatments and documentations can play.

In response to Ehrle's critique of the treatment of the Hebrew Ecclesiasticus, Nicholson wrote "I was anxious to do nothing more than I could help". His concern about unproven repair techniques that might damage collections further was shared at the St. Gall Conference. Here, tested repair methods were judged to be the viable way forward. Nicholson summarised this in his report to the curators of the Bodleian Library, "The conference recommends as the deterioration of manuscripts only proceeds slowly, that till definite results have been laid before members through the committee - at any rate till autumn 1899 - only such means should be employed as in the individual case guarantee the greatest relative safety and do not prevent the use of better processes which might be discovered in the future" (Nicholson 1898).

Acknowledgements: We would like to express our thanks to: David Helliwell for his guidance on aesthetic matters regarding the design of the scrolls and their significance, Valerie Lee for her precious advice during the treatment, Helen Wilson and our colleagues Virginia Llado-Buisan, Robert Minte and David Howell for their support. 


\section{References}

Benefactors' Register 1600 - 1688. Unpublished manuscript, Library Records b. 903, University of Oxford: Bodleian Libraries.

Binders Book January 1883 - May 27 1885. Unpublished record, Library Records c. 1419, University of Oxford: Bodleian Libraries.

Bodleian Library Papers 1888-1892. Unpublished papers, Library Records d. 16, University of Oxford: Bodleian Libraries.

Ehrle, F.: Della conservazione e del restauro dei manoscritti antichi. Rivista Delle Biblioteche E Degli Archivi 9 (1898): 5-11, 19-25.

Helliwell, D.: Report to Mrs. Segal. Unpublished document. University of Oxford, Bodleian Libraries, 1977.

Iannuccelli, S., Sotgiu, S., (eds.): La pulitura a umido di opera d'arte su carta con gel rigidi di Gellano: presupposti teorici, metodologia applicative e verifica analitica, Cesmar7, Quaderno N. 11. Saonara (Padova): Il prato casa editrice, 2012.

Nicholson, E. W. B.: Report by Bodley's Librarian to the Curators of the Bodleian Library, on the Conference held at St. Gallen, Sept. 30 and Oct. 1, 1898, upon the preservation and repair of old MSS. In: The St. Gallen Conference 1898, unpublished record, Library Records c. 1429 , University of Oxford: Bodleian Libraries.

Schwarz, I.: A pre-packaged $\alpha$-amylase poulticing system: Albertina-Kompresse. The Book and Paper Group Annual 19 (2000): 19-26.

Segal, J., Cooper, D.: The use of enzymes to release adhesives. Paper Conservator 2 (1977): 47-50.

Suzuki, H., Kamba, N.: An application of a new roller clamp for scrolls: Toward an approach to symptomatic treatment in conservation. Journal of the Japan Society for the Conservation of Cultural Property 54 (2009): 52-65.

The St. Gallen Conference 1898. Unpublished papers, Library Records c. 1429, University of Oxford: Bodleian Libraries.

Vaisey, D. G.: E.W.B. Nicholson and the St. Gall conference, 1898. The Bodleian Library Record IX(2) (1974): 101-113.

\section{Material sources}

Rayon (12 and $\left.18 \mathrm{~g} / \mathrm{m}^{2}\right)$; Sanmoa; Blackless

Yoshida Co., Ltd, Kyoto, Japan

Usumino paper $\left(9-12 \mathrm{~g} / \mathrm{m}^{2}\right)$

Hasegawa Washi Kobo, Mino-city, Japan

Sekishu paper

Masumi Corporation, Tokyo, Japan 
Red Star Xuan paper, catalogue number P3-1, from Anhui Paper Factory China

Man Luen Choon, Hong Kong

Albertina Compress

Klug Conservation, Immenstadt, Germany

Gellan gum KELCOGEL ${ }^{\circledR}$ CG-LA; Gelatine Type B

GMW - Gabi Kleindorfer, Vilsheim, Germany

Calcium acetate hydrate

VWR International Ltd., Lutterworth, UK

Methocel ${ }^{\circledR}$ A4M

Dow Chemical Company, Stade, Germany

Kimtech Science delicate task wipes

Kimberly-Clark Professional, Reigate, UK

HotRox electronic hand warmer

www.thehotrox.co.uk

\section{Zusammenfassung}

Himmel und Erde: Zwei chinesische Rollbilder aus der Ming-Dynastie. Frühere Reparaturen und heutige Konservierungsmaßnahmen

Zwei chinesische Rollbilder aus der Ming-Dynastie mit Darstellungen des Himmels und der Erde kamen 1684 als Schenkung an die Bodleian Library. Es handelt sich dabei wahrscheinlich um Gebrauchsobjekte, die in der späten Ming-Dynastie gedruckt worden waren. Internen Aufzeichnungen zufolge wurden die beiden Rollbilder 1883 beschnitten, mit Transparentpapier ausgebessert, auf Stoff kaschiert und in einer dem Objekt nicht angemessenen Art montiert. Der vorliegende Beitrag beschreibt die Restaurierungsmaßnahmen des damaligen Bibliothekars der Bodleian Library, in denen sich seine Teilnahme in der der St. Gallener Konferenz 1898 widerspiegeln. Die Konservierung der Rollbilder, die 2015 abgeschlossen werden konnte, wurde von früheren Eingriffen, aktuellen ethischen Überlegungen und naturwissenschaftlichen Untersuchungen geleitet. Um die starke Verklebung zwischen dem Transparentpapier und der fragilen Oberfläche der Rollbilder zu lösen, wurden zahlreiche Tests mit Gellan und der Albertina Kompresse durchgeführt. Die Wiederherstellung der Funktion der Objekte als Rollbilder konnte nur durch die Anwendung traditioneller RollbildMontagetechniken und der Neuinterpretation des chinesischen Montage-Stils aus der Perspektive westlicher Papierrestaurierung gelingen. Der Beitrag thematisiert auch die Erfahrung, die durch eine Behandlung zweier Kunstwerke mit fast identischen Problemstellungen gewonnen wurde. 


\section{Résumé}

Entre terre et ciel: une paire de rouleaux suspendus Ming; des réparations passées à la restauration d'aujourd'hui

Une paire de rouleaux chinois représentant la terre et le ciel a été donnée à la Bibliothèque Bodleian en 1684. Ceux-ci sont considérés comme étant des éléments éphémères imprimés au cours de la fin de la dynastie Ming. Les rapports indiquent qu'en 1883, les rouleaux ont été coupés, réparés avec des patchs de papier transparent, doublés avec du tissu et monté de manière non appropriée. Dans cet article, nous examinons les mesures de restauration et de préservation prises par le bibliothécaire d'antan de la Bodleian et apportons une réflexion sur sa participation à la Conférence de Saint-Gall en 1898. Les choix de traitement de restauration des rouleaux achevé en 2015 ont été influencés par les réparations antérieures, les considérations éthiques actuelles et les résultats d'analyses scientifiques. Rompre le lien fort entre les patchs de papier transparent et la surface fragile des rouleaux a nécessité des expérimentations avec des compresses Albertina et de la gomme gellane. La remise en état fonctionnel des rouleaux suspendus a impliqué l'utilisation de techniques traditionnelles de montage de rouleaux suspendus et la réinterprétation du style de montage chinois avec une perspective de restauration occidentale. Nous abordons également l'expérience acquise par le traitement de deux autres objets présentant des problèmes presque identiques.

\section{Authors}

Marinita Stiglitz graduated in Art History at the University of Rome La Sapienza and studied conservation in Italy and in the United States where she specialised in works on paper and particularly on East Asian art on paper. She worked as a freelance conservator in Rome and in 2004 she joined the Conservation and Collection Care Department of the Bodleian Libraries, University of Oxford, UK, where she is currently Head of Paper Conservation.

Julia Bearman has a degree in Fine Art (1988) and a postgraduate diploma in conservation from Camberwell College of Arts London (2003). Following a twoyear internship she worked as a conservator in museums and archives. Julia now specialises in the conservation of works on paper at the Bodleian Libraries, University of Oxford, UK. 